were typical grassland soils in the area throughout the ice ages. They were typical of each recession of the glacior and are now buried deep under the present land surface. At present, natural tree growth is practically restricted to river-bottom lands and ravines, and there is very little tendency for the woodlands to spread out over the plains.

\section{The Weather Service in Great Britain}

A NEAT little pamphlet entitled "Your Weather Service", prepared by the Meteorological Office and Central Office of Information (revised edition; pp. $52+8$ plates. London: H.M.S.O., 1955 ; $1 s .6 d$. net), describes in popular form the organization of the Meteorological Office, the making of meteorological observations, and their collection and use. both in weather forecasting and in the longer-term climatological work which the Meteorological Office performs in its capacity as the public memory of the weather. The terms used in broadcast weather forecasts are defined, and maps show the areas used in the forecasts broadcast for the British Isles and the adjacent sea areas. The pamphlet gives full details of how to obtain special weather forecasts and meteorological advice, and ends with a table of the normal temperatures of each month in each of the areas used in the broadcasts and a detailed table of mean and extreme temperatures, sunshine, relative humidity, fog, thunder, snow and wind at Kew Observatory. Plates show the making of surface and upper-air observations and their collection, the plotting of them on charts, and the testing of instruments. One plate shows in diagrammatic form the very wide sphere of applications from which inquiries are received in the British Climatology Branch of the Office, ranging from "where to live" to the design of cooling towers at power stations. On the muchdiscussed subject of "old-fashioned summers", there is no evidence that Britain is either warmer or colder than it was a century ago. The pamphlet describes the services of reference on the spot and of lending of the Meteorological Office Library, which contains the greatest collection of meteorological literature in Britain and is one of the largest in the world. The pamphlet also gives an outline of the publications, from the Daily Weather Report to the highly specialized research series of Geophysical Memoirs prepared in the Office.

\section{Geophysics in Pakistan}

THE director of the Meteorological Service of Pakistan, Mr. S. N. Naqvi, began last year the publication of a duplicated series entitled "Geophysical Review". Part 4, "Technical Progress Review, No. 7" (September 30, 1955), describes the current state of geophysical research in Pakistan, and in particular the work in progress on atmospheric physics, geomagnetism and seismology. In cloud physics, condensation on large hygroscopic particles has been studied under the guidance of Dr. E. M. Fournier d'Albe, and trials of cloud-seeding by spraying salt particles into the air have been made. Actinometers have been brought into use and their records analysed to obtain the usual statistics of solar radiation and the 'measure of turbidity' which is the exponent of the Rayleigh transmission factor of the solar beam. The Agrimeteorological Observatory has worked on soil temperature and water content at depths up to $1 \mathrm{~m}$. in an orchard in relation to the minimum water requirements of the fruit trees. The Geomagnetic Section has studied the variation of the scale values and temperature coefficient of the horizontal force magnetometer, ionospheric structure and, with a Dobson spectrometer, the variation in ozone content of the air. The Seismological Observatory has installed accelographs at Quetta and Sylhet (East Pakistan), the records of which will be valuable in the construction of buildings to resist earthquakes, and has made detailed studies of the recent larger shocks in the Dominion. Geophysical research is developing rapidly in Pakistan, and the Meteorological Service of Pakistan, one of the most recently formed such services in the British Commonwealth, is doing valuable service in publishing this record of progress up to date.

\section{Higher Education in the United States}

Is the September issue of the Annals of the American Academy of Political and Social Science, under the title "Higher Education under Stress", is presented a comprehensive picture of the issues confronting higher education in the United States. Three general papers, by F. J. Brown on a long-range view of higher education, by G. K. Chalmers on the purpose of learning, and by $M$. H. Trythen on meeting manpower needs, are followed by eight others dealing with specific issues in the United States. These are of slight interest to the British reader, with the exception of Dr. H. D. Gideonse's "Academic Freedom : a Decade of Challenge and Clarification" and Dr. H. E. Wilson's review of the role of the university in international relations; but for these two papers alone the number will be welcomed by many in Britain. The greater part of the issue is devoted to the papers presented at the Conference on Methods of Financing Higher Education, held in Philadelphia during May 20-21, 1955. For the most part they are concerned with specifically American issues which have no close counterpart elsewhere, and, while the issue forms an admirable supplement which brings up to date J. D. Millett's report on "Financing Higher Education in the United States", published in 1952, except for the papers indicated it throws little light on the problems with which the university administrator or teacher in Britain is confronted.

\section{Education through Physics}

What qualities does the world expect of a welleducated man? That he should have a tough and inquiring mind, able, and indeod anxious, to trckle new problems, new situations. That he should be creative, not hidebound, independent and not relying solely on the minds of others. That he should be well informed generally and really knowledgeable about certain subjects or parts of subjects. That he should appreciate spiritual and æsthetic values. That he should be intellectually honest, able to recognize a hard fact, and not afraid to give up preconceived ideas in the face of demonstrable proof. That he should be able to express himself clearly, convincingly and concisely in writing and in speech. That he should be able to live with and collaborate with others, showing the tolerance which arises from an understanding of studies and beliefs other than his own, but not tolerance of slovenliness of any kind. That he should exhibit the qualities of perseverance and humility, and above all, of judgment. These views were put forward by Prof. F. A. Vick at a meoting of the Education Group of the Institute of Physics. Prof. Vick does not pretend that all these qualities can be acquired solely from courses in physics, although he believes that most, if not all, 